\title{
Long-term trends in river water temperature: a case study of the Raba River (Polish Carpathians)
}

\author{
Mariola Kędra ${ }^{1, *}$ \\ ${ }^{1}$ Cracow University of Technology, Department of Environmental Engineering, Institute of Engineering and Water Management, \\ Warszawska 24, 31-151 Cracow, Poland
}

\begin{abstract}
This study analyses potential trends in river water temperature (Tw) over a period of 50 years (1960-2009). The study area is located in the Raba catchment in the Polish Carpathians. The aim of the study was to evaluate long-term trends in daily Tw for each season of the year as well as to compare the direction of these trends for sites located some distance upstream and downstream from the Dobczyce Reservoir (DR), built in 1986 on the Raba River. For autumn and winter, increases in mean, median, and minimum Tw are significant for the downstream site $(39 \mathrm{~km}$ from the DR), with a rate of change of $0.18-0.26{ }^{\circ} \mathrm{C}$ per decade. Contrasting results were obtained for the spring and summer seasons; significant increases $\left(0.22-0.47^{\circ} \mathrm{C}\right.$ per decade) in mean, median, and maximum $\mathrm{Tw}$ were found for the upstream site, in concordance with seasonal air temperature trends, but a significant decrease in maximum Tw $\left(-0.42\right.$ and $-0.35{ }^{\circ} \mathrm{C}$ per decade, respectively) was identified for the downstream site. The revealed discrepancies in the direction of seasonal trends for the upstream and downstream sites studied suggest an anthropogenic impact on Tw downstream from the DR. Overall, a significant increase in summer Tw suggest the need for appropriate flowing water management that would mitigate adverse effects of climate warming on the fluvial environment.
\end{abstract}

\section{Introduction}

Water temperature (Tw) in streams and rivers is one of the most important determinants of aquatic life conditions. Tw regulates the rate of biological and chemical reactions affecting the growth, development, and survival of aquatic organisms as well as their distribution within a fluvial environment and across geographic regions [1]. Tw depends on heat exchange processes between a water body and its surroundings, that is, at the surface and bed of rivers [2]. The exchange of heat across the water surface is determined by shortwave and long-wave radiation, evaporation, and conduction between water and ambient air; therefore, changing meteorological conditions such as air temperature, solar radiation, cloud cover, relative humidity, and wind speed induce changes in water temperature [2-3] to an extent dependent on insulating and buffering processes, which operate within a stream system [4].

The impact of climatic factors, mainly air temperature, on the functioning of aquatic ecosystems is extensively discussed in the context of progressive climate change [5-13]. The world-wide warming trend in mean surface air temperature of $0.12{ }^{\circ} \mathrm{C}$ per decade (1951-2012) [14] together with likely changes in precipitation [15] may create flow and thermal conditions unfavourable for native aquatic biota. As stream temperature measures the amount of heat energy per unit volume of water [4], hence even relatively shortterm (weekly, monthly) decreases in flow volume (induced by climatic or anthropogenic factors such as water withdrawal) can temporarily enhance a potential increase in $\mathrm{Tw}$, with detrimental consequences for aquatic organisms. In particular, fish, aquatic ectothermic vertebrates [16], can tolerate only a certain temperature range [1] and respond rapidly to the temperature of their habitat; temperature can therefore be viewed as an ecological resource shared between three thermal guilds (cold, cool, and warm water fishes) [16]. A progressive increase in $\mathrm{Tw}$ will result in warmer fluvial conditions unsuitable for those native fish species which prefer colder water. In that case, even temperature variation produced by habitat heterogeneity [17] may be insufficient refuge for them.

The impact of anthropogenic factors, including land use change and in-river impoundments, on the thermal regime of rivers has been well documented [18-23]. In particular, removal of vegetation (riparian or upland) makes small streams more prone to a rise in Tw due to their relatively low thermal capacity $[4,24]$. Dams alter downstream thermal conditions depending on their size, and operational mode and water release mechanism [20, 22]. Downstream of dams with hypolimnetic (bottom layer) releases, the thermal regime is cooler in summer and warmer in winter, compared with the predam

Corresponding author: mariola.kedra@iiigw.pk.edu.pl 
conditions, affecting the populations and types of species present [22]. Hypolimnetic releases can deteriorate the synchronous behaviour of air and water temperatures and significantly modify water temperature dynamics in the downstream river reach [25-26]. Modelling results indicate that climate change impact will be more pronounced downstream of dams with epilimnetic (surface layer) water releases than with hypolimnetic releases [6].

The aim of this study is: (1) to assess potential longterm (50-year) trends in river water temperature for each season of the year; (2) to compare the direction of these trends for sites located some distance upstream and downstream from a relatively large reservoir with hypolimnetic water releases, which was built on a mountain river in the Polish Carpathians. As water temperature is regarded a fundamental ecological variable [27] an assessment of potential changes in Tw, especially long-term trends, appears necessary and vital. This should facilitate appropriate management of the river thermal regime - an integral part of environmental flow [27], with emphasis on remedial action mitigating adverse effects of climate warming on natural fluvial environments. Moreover, important differences in the direction of trends in water temperature for upstream and downstream sites can further underscore the usefulness of river reaches downstream from hypolimnetic dams (tailwaters) for desirable coldwater trout fisheries [28].

\section{Materials and methods}

\subsection{Study area}

The research was conducted on the Carpathian river Raba, the right-bank tributary of the upper Vistula River in southern Poland (Fig. 1). From its source in the Gorce Mountains $780 \mathrm{~m}$ above sea level (a.s.1.) to its mouth $180 \mathrm{~m}$ a.s.1., the Raba River is $132 \mathrm{~km}$ in length [29]. The Raba catchment covers an area of $1,537 \mathrm{~km}^{2}$ [29], with the highest peak (Turbacz: $1,310 \mathrm{~m}$ ) being located in the Gorce Mountains, and the lowest elevation at the Raba River mouth. The rock layer underlying the Raba catchment is primarily composed of sandstone, shale, marl, loam, and gravel [30].

Climate conditions in the study area vary depending on location. In the lower-lying parts of the catchment, the air temperature is higher, with an annual average of $6-8{ }^{\circ} \mathrm{C}$, and precipitation totals of $600-800 \mathrm{~mm}$ a year. The highest peaks in the Gorce Mountains are characterised by a cool climate with the annual mean air temperature below $4{ }^{\circ} \mathrm{C}$ and annual precipitation totals reaching 1,200 $\mathrm{mm}$. Precipitation totals increase as the elevation increases; however, this tendency is disturbed by the influence of mesorelief landforms [30].

The Raba catchment area is $57.6 \%$ agricultural, while forest and developed land comprise $35.4 \%$ and $6.2 \%$, respectively, while water covers $0.8 \%$ [31]. A retention reservoir with a holding capacity of $125 \mathrm{mln}$ $\mathrm{m}^{3}$ was built in 1986 on the Raba River [32]. The dam is $30.5 \mathrm{~m}$ high, located at the 60.1 river kilometre, is equipped with a gated spillway and fixed, low-level intakes. The Dobczyce Reservoir (DR) is the main source of drinking water for the city of Cracow. Its function is flood prevention, and increasing base flows in the Raba River. The dam is also used for electric energy generation [32].

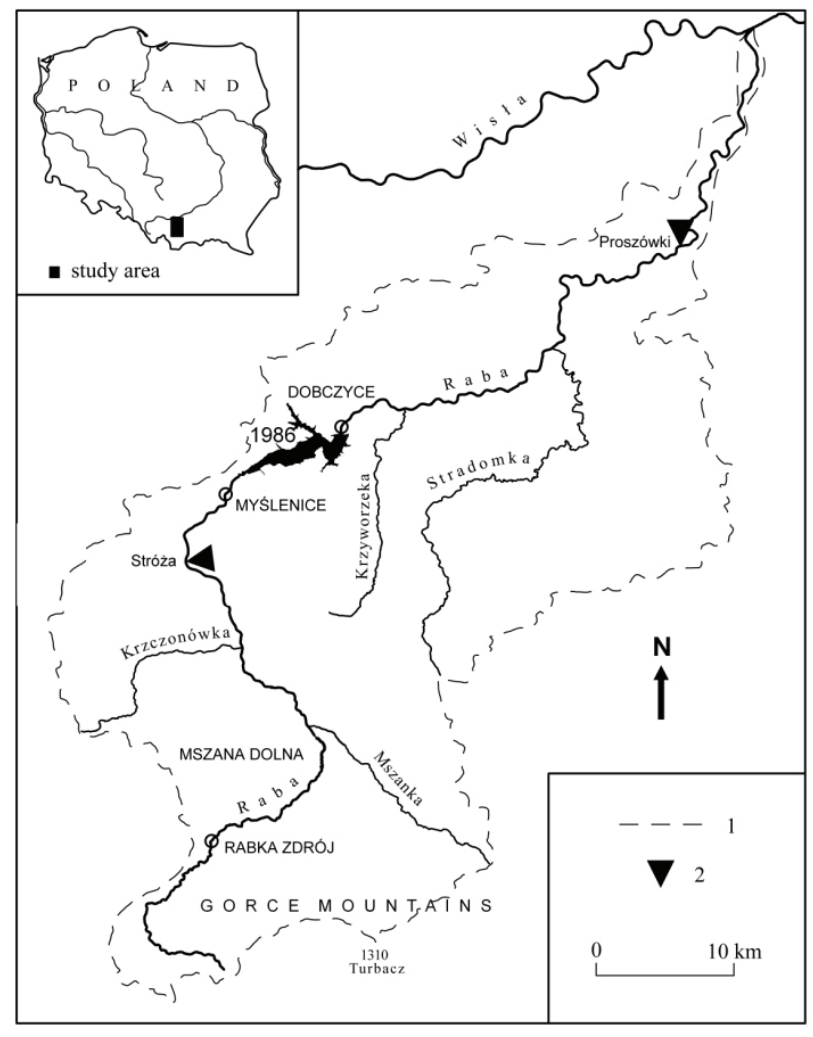

Fig. 1. Study area - the Raba River catchment with larger tributaries: (1) catchment boundary, (2) stream gauging sites.

\subsection{Data and methods}

\subsubsection{Data}

The examined water temperature series consist of daily observations (at 6:00 Coordinated Universal Time, or CUT) made consecutively at two gauging sites (Stróża and Proszówki) situated on the Raba River (Table 1). The data for the years 1960-2009 (December 1959 November 2009) were made available for research purposes by the Polish Institute of Meteorology and Water Management-the National Research Institute, and in some cases were obtained from Poland's statepublished surface water yearbooks. The available water temperature series for Proszówki ends in 2009; this determined the time period studied. The sites Stróża and Proszówki are located along the upper and lower course of the Raba River, approximately $21 \mathrm{~km}$ and $39 \mathrm{~km}$ from the DR dam, respectively. Moreover, gridded data series of daily mean air temperature for Stróża and Proszówki for 1962-2009 (December 1961 - November 2009) were extracted from the high quality, homogenised CARPATCLIM Database (C) European Commission JRC [33] for comparison purposes. The data are available for the years 1961-2010 (January $1^{\text {st }}$ to December $31^{\text {st }}$ ) only. 
Table 1. Physical characteristics of the study sites [29] and descriptive statistics of daily water temperature (Tw) data for the 50-year period (1960-2009).

\begin{tabular}{|c|c|c|}
\hline Statistic & Stróża site & Proszówki site \\
\hline Latitude (N) & $49^{\circ} 47^{\prime} 49^{\prime \prime}$ & $49^{\circ} 59^{\prime} 47^{\prime \prime}$ \\
\hline Longitude (E) & $19^{\circ} 55^{\prime} 29^{\prime \prime}$ & $20^{\circ} 26^{\prime} 18^{\prime \prime}$ \\
\hline $\begin{array}{l}\text { River length } \\
\qquad(\mathrm{km})\end{array}$ & 80.6 & 21.5 \\
\hline $\begin{array}{l}\text { Drainage area } \\
\qquad\left(\mathrm{km}^{2}\right)\end{array}$ & 644.1 & 1470.4 \\
\hline $\begin{array}{l}\text { Median elevation } \\
(\mathrm{m})\end{array}$ & 581 & 423 \\
\hline $\begin{array}{c}\text { Mean catchment slope } \\
(-)\end{array}$ & 0.030 & 0.016 \\
\hline $\begin{array}{l}\text { Mean discharge } \\
\qquad\left(\mathrm{m}^{3} \mathrm{~s}^{-1}\right)\end{array}$ & 10.10 & 17.02 \\
\hline$\underset{\left({ }^{\circ} \mathrm{C}\right)}{\operatorname{Minimum} \mathrm{Tw}}$ & 0.0 & 0.0 \\
\hline $\begin{array}{l}\operatorname{Maximum} \mathrm{Tw} \\
\left({ }^{\circ} \mathrm{C}\right)\end{array}$ & 22.2 & 24.8 \\
\hline $\begin{array}{l}\text { Median Tw } \\
\left({ }^{\circ} \mathrm{C}\right)\end{array}$ & 7.2 & 8.9 \\
\hline $\begin{array}{c}\text { Mean Tw } \\
\left({ }^{\circ} \mathrm{C}\right)\end{array}$ & 7.6 & 9.1 \\
\hline $\begin{array}{c}\text { Standard deviation of } \\
\operatorname{Tw}\left({ }^{\circ} \mathrm{C}\right)\end{array}$ & 5.9 & 6.7 \\
\hline
\end{tabular}

\subsubsection{Methods}

After visual inspection of daily temperature data, compiled in a Microsoft ${ }^{\circledR}$ Excel 2007 spreadsheet, a quality check was performed in order to identify spurious values. Next, each series was arranged as the matrix $\boldsymbol{T}_{k i}$, where the index $k$ (for row) represents a day of the year $(k=1, \ldots, 366)$, and the index $i$ (for column) represents a year $(i=1, \ldots, n)$, and $n=50$. For the relevant rows of the matrix $(1-91,92-183,184-275$, 276-366), arithmetic mean, median, minimum, and maximum values were calculated as $n$-element series $\left\{x_{i}\right\}$ for each season (winter-autumn) of the year (19602009). Next, trend analysis was performed on each seasonal series separately in order to evaluate the strength of potential monotonic trends in seasonal temperature. The linear model of time trend was assumed in the form: $x(t)=a \cdot t+b$, where $a$ is the slope coefficient, $b$ is the intercept, and $t$ is time. The nonparametric, 2-sided Mann-Kendall (MK) test [34-36] was used. The null hypothesis of no trend $\left(\mathrm{H}_{0}: a=0\right)$ was tested equivalently $\left(\mathrm{H}_{0}: \tau=0\right)$, using Kendall's rank correlation coefficient $\tau$ [36-38] at the significance level $\alpha$ : 0.05 (medium evidence) and 0.01 (strong evidence). The $\tau$ is expressed as:

$$
\begin{gathered}
\tau=\frac{2 S}{n(n-1)} \\
S=\sum_{i=1}^{n-1} \sum_{j=i+1}^{n} \operatorname{sign}\left(x_{j}-x_{i}\right)
\end{gathered}
$$

where $S$ is Kendall's $S$ statistic, and $\operatorname{sign}(x)$ is the sign function. The magnitude of trends was determined using Theil-Sen's slope [36-38] as a robust estimate of the slope, with the slope and intercept defined as:

$$
\begin{gathered}
\hat{a}=\operatorname{median}\left(\frac{x_{j}-x_{i}}{t_{j}-t_{i}}\right), i=1, \cdots, n-1, j=i+1, \cdots, n \\
\hat{b}=\operatorname{median}\left(\left\{x_{i}\right\}_{i=1}^{n}\right)-\hat{a} \operatorname{median}\left(\left\{t_{i}\right\}_{i=1}^{n}\right)
\end{gathered}
$$

No assumption of normality, but serial interdependence is required [36]. Therefore, the trend-free pre-whitening procedure (TFPW) [39] was applied to each data series.

\section{Results}

For water temperature, significant trends $(p<0.05)$ were identified for each season of the year (Table 2). For autumn (September-November) and winter (DecemberFebruary), increases in mean, median, and minimum Tw were found for the downstream site only (Proszówki), with a rate of change of $0.22-0.26{ }^{\circ} \mathrm{C}$ per decade for autumn (Fig. 2), and $0.18-0.24{ }^{\circ} \mathrm{C}$ per decade for winter (Fig. 3). For spring (March-May), a significant increase in maximum $\mathrm{Tw}\left(0.47^{\circ} \mathrm{C}\right.$ per decade) was identified for the upstream site (Stróża, Fig. 4a); in contrast, a significant decrease in maximum $\mathrm{Tw}\left(-0.42{ }^{\circ} \mathrm{C}\right.$ per decade) was found for the downstream site (Fig. 4b), together with an increase in minimum $\mathrm{Tw}\left(0.03{ }^{\circ} \mathrm{C}\right.$ per decade, Fig. 4c). For summer (June-August), increases in mean, median, and maximum $\mathrm{Tw}$ are significant for the upstream site $\left(0.22-0.29{ }^{\circ} \mathrm{C}\right.$ per decade, Figs. $\left.5 \mathrm{a}-\mathrm{c}\right)$; in contrast, a significant decrease in maximum $\mathrm{Tw}$ was identified for the downstream site $\left(-0.35^{\circ} \mathrm{C}\right.$ per decade, Fig. 5d).

Table 2. Rate of change $\hat{a}\left({ }^{\circ} \mathrm{C}\right.$ decade $\left.{ }^{-1}\right)$ for water temperature (Tw) in each season of the year (1960-2009) based on Theil-Sen's slope estimation [37-38] with trend free prewhitening [39]. Statistical significance of the trends was evaluated via the 2-sided Mann-Kendall test [34-35].

\begin{tabular}{|c|c|c|c|c|}
\hline Tw statistic & $\begin{array}{c}\text { Winter } \\
\text { (Dec- } \\
\text { Feb) }\end{array}$ & $\begin{array}{c}\text { Spring } \\
\text { (Mar- } \\
\text { May) }\end{array}$ & $\begin{array}{c}\text { Summer } \\
\text { (Jun- } \\
\text { Aug) }\end{array}$ & $\begin{array}{c}\text { Autumn } \\
\text { (Sep- } \\
\text { Nov) }\end{array}$ \\
\hline $\begin{array}{c}\text { Mean } \\
\text { (Stróża) }\end{array}$ & 0.04 & 0.21 & $0.25^{*}$ & -0.08 \\
\hline $\begin{array}{c}\text { Median } \\
\text { (Stróża) }\end{array}$ & 0.00 & 0.14 & $0.22^{*}$ & 0.00 \\
\hline $\begin{array}{c}\text { Minimum } \\
\text { (Stróża) }\end{array}$ & 0.00 & 0.00 & 0.24 & -0.04 \\
\hline $\begin{array}{c}\text { Maximum } \\
\text { (Stróża) }\end{array}$ & 0.30 & $0.47 * *$ & $0.29 * *$ & 0.06 \\
\hline $\begin{array}{c}\text { Mean } \\
\text { (Proszówki) }\end{array}$ & $0.24^{* *}$ & -0.13 & -0.10 & 0.22 \\
\hline $\begin{array}{c}\text { Median } \\
\text { (Proszówki) }\end{array}$ & $0.18^{* *}$ & -0.21 & -0.07 & $0.26^{*}$ \\
\hline $\begin{array}{c}\text { Minimum } \\
\text { (Proszówki) }\end{array}$ & 0.00 & $0.03 *$ & 0.00 & $0.22^{*}$ \\
\hline $\begin{array}{c}\text { Maximum } \\
\text { (Proszówki) }\end{array}$ & 0.29 & $-0.42^{*}$ & $-0.35^{*}$ & 0.00 \\
\hline
\end{tabular}

$*$ data significant at $p<0.05 ; * *$ data significant at $p<0.01$. 

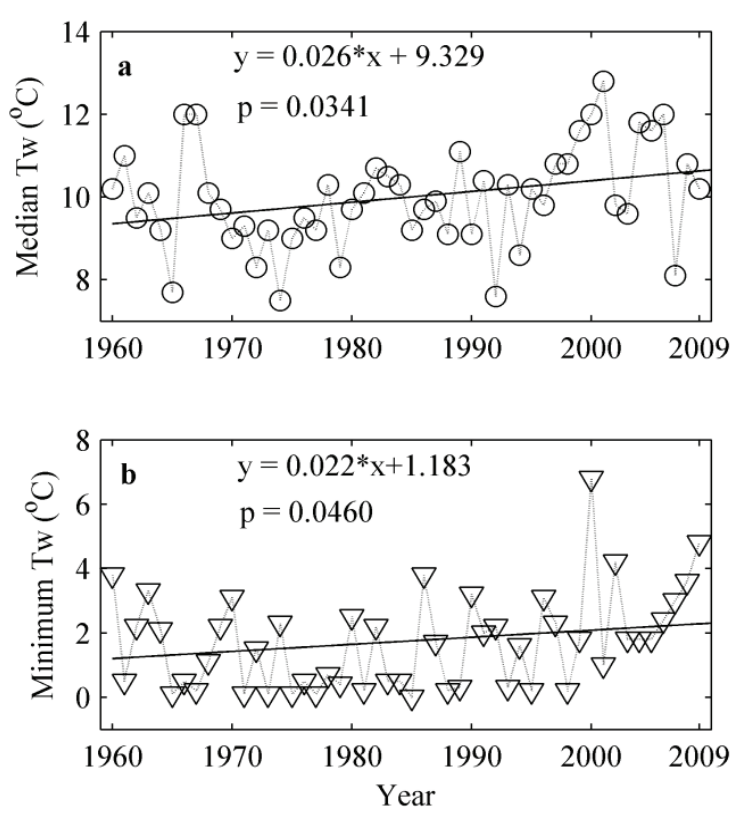

Fig. 2. Autumn water temperatures (Tw) at Proszówki (downstream of the DR dam) for the 50-year period (19602009) with significant trends shown in: (a) median Tw; (b) minimum Tw.
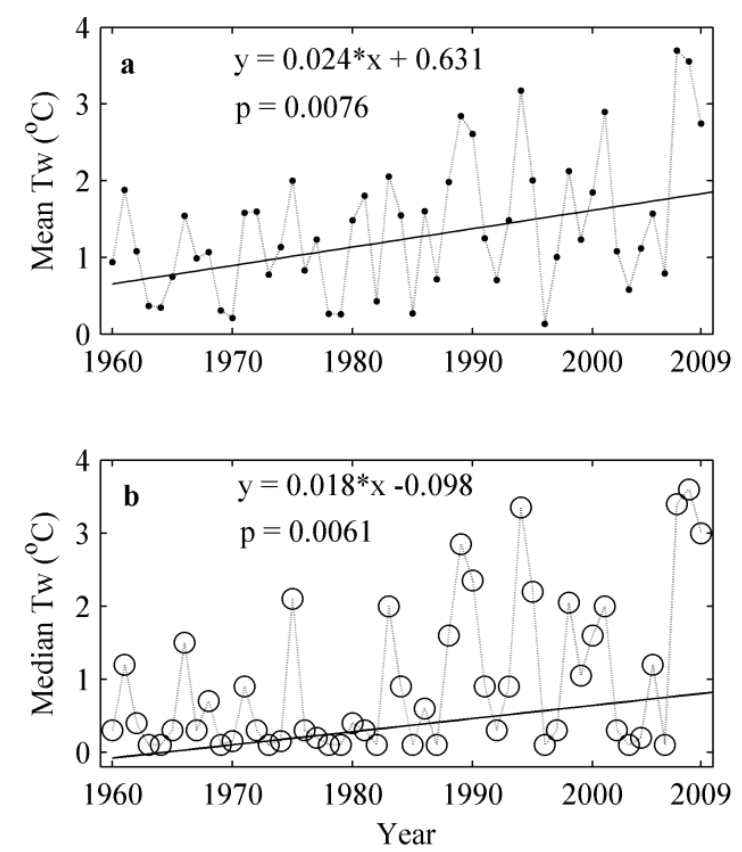

Fig. 3. Winter water temperatures (Tw) at Proszówki (downstream of the DR dam) for the 50-year period (19602009) with significant trends shown in: (a) mean Tw; (b) median Tw.

In order to explain the detected differences in seasonal Tw, analogous trend analysis was performed for seasonal air temperature (Ta) for the period 1962-2009. As listed in Table 3, significant trends $(p<0.05)$ were found for each season of the year except autumn. All seasonal trends in Ta were increasing, and highly consistent for both the upstream and downstream sites.
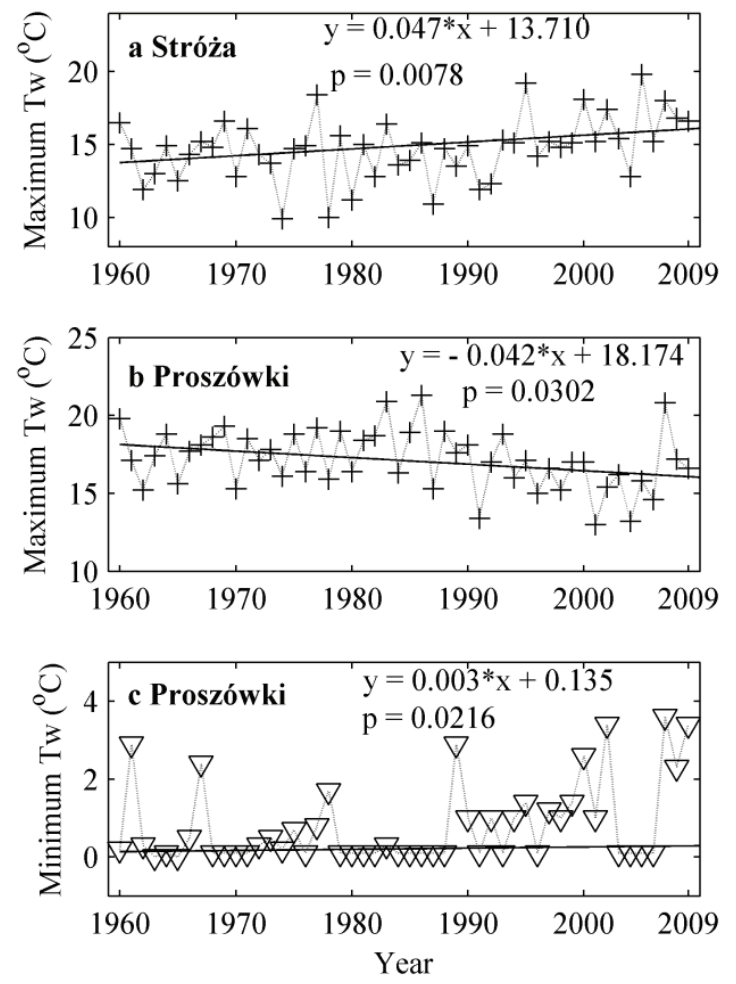

Fig. 4. Spring water temperatures (Tw) for the 50-year period (1960-2009) with significant trends shown in: (a) maximum Tw at Stróża (upstream of the DR dam); (b)-(c) maximum and minimum Tw at Proszówki (downstream of the DR dam), respectively.

Table 3. Rate of change $\hat{a}\left({ }^{\circ} \mathrm{C}\right.$ decade $\left.e^{-1}\right)$ for gridded air temperature (Ta) in each season of the year (1962-2009) based on Theil-Sen's slope estimation [37-38] with trend free pre-

whitening [39]. Statistical significance of the trends was evaluated via the 2-sided Mann-Kendall test [34-35].

\begin{tabular}{|c|c|c|c|c|}
\hline Tw statistic & $\begin{array}{c}\text { Winter } \\
\text { (Dec- } \\
\text { Feb) }\end{array}$ & $\begin{array}{c}\text { Spring } \\
\text { (Mar- } \\
\text { May) }\end{array}$ & $\begin{array}{c}\text { Summer } \\
\text { (Jun- } \\
\text { Aug) }\end{array}$ & $\begin{array}{c}\text { Autumn } \\
\text { (Sep- } \\
\text { Nov) }\end{array}$ \\
\hline $\begin{array}{c}\text { Mean } \\
\text { (Stróża) }\end{array}$ & $0.48^{*}$ & $0.37 * *$ & $0.44^{* *}$ & 0.10 \\
\hline $\begin{array}{c}\text { Median } \\
\text { (Stróża) }\end{array}$ & 0.45 & $0.30^{*}$ & $0.47^{*}$ & 0.19 \\
\hline $\begin{array}{c}\text { Minimum } \\
\text { (Stróża) }\end{array}$ & $0.87^{*}$ & 0.68 & $0.42^{*}$ & -0.13 \\
\hline $\begin{array}{c}\text { Maximum } \\
\text { (Stróża) }\end{array}$ & $0.70^{*}$ & 0.30 & $0.53^{* *}$ & 0.12 \\
\hline $\begin{array}{c}\text { Mean } \\
\text { (Proszówki) }\end{array}$ & $0.52^{*}$ & $0.38^{* *}$ & $0.46^{* *}$ & 0.12 \\
\hline $\begin{array}{c}\text { Median } \\
\text { (Proszówki) }\end{array}$ & 0.42 & $0.37 * *$ & $0.48^{* *}$ & 0.22 \\
\hline $\begin{array}{c}\text { Minimum } \\
\text { (Proszówki) }\end{array}$ & 0.75 & 0.52 & $0.45^{*}$ & -0.11 \\
\hline $\begin{array}{c}\text { Maximum } \\
\text { (Proszówki) }\end{array}$ & $0.79 *$ & 0.18 & $0.52^{*}$ & 0.06 \\
\hline
\end{tabular}

$*$ data significant at $p<0.05$; ** data significant at $p<0.01$. 

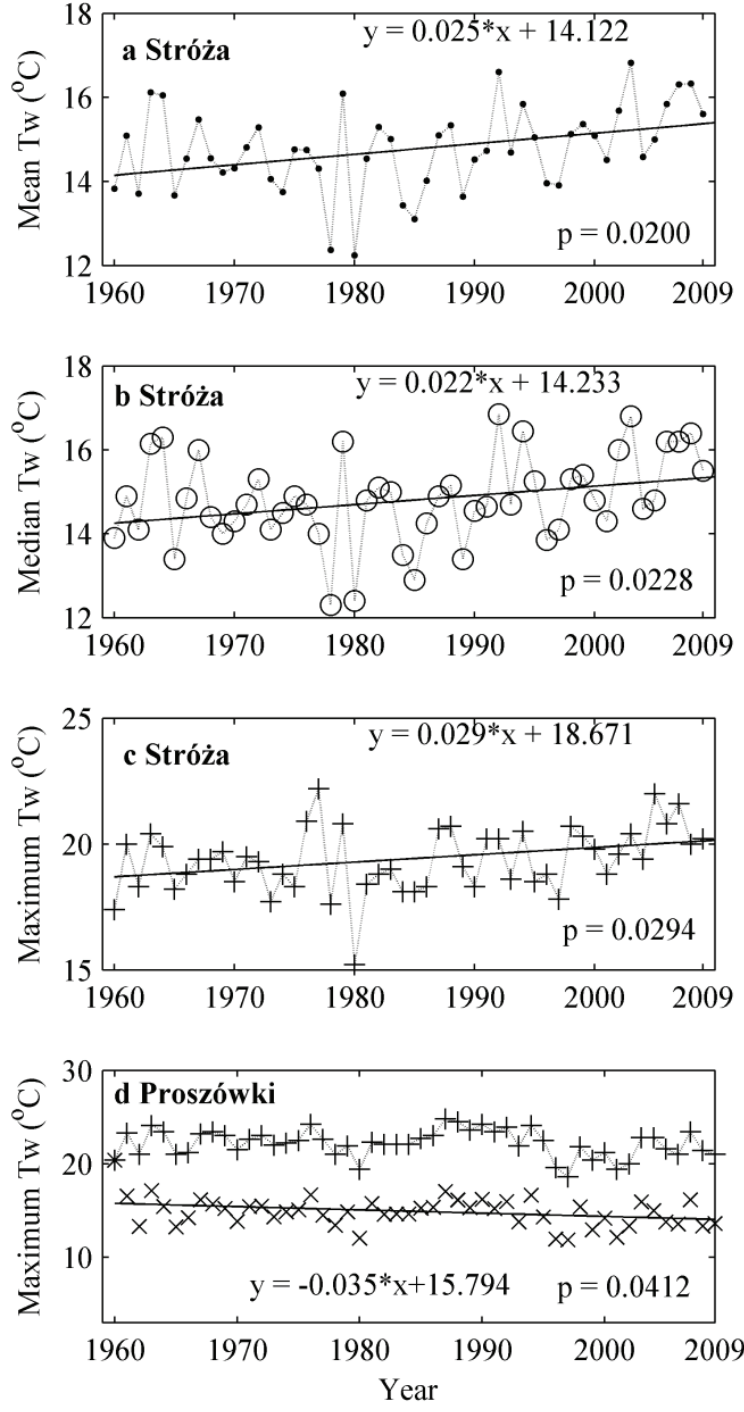

Fig. 5. Summer water temperatures (Tw) for the 50-year period (1960-2009) with significant trends shown in: (a)-(c) mean, median, and maximum Tw at Stróża (upstream of the DR dam); (d) maximum Tw (+original series, $x$ pre-whitened series) at Proszówki (downstream of the DR dam), resp.

Increases in mean, minimum, and maximum $\mathrm{Ta}$ during the winter $\left(0.48-0.87{ }^{\circ} \mathrm{C}\right.$ per decade) were followed by increases in mean and median Ta during the spring (0.30-0.37 ${ }^{\circ} \mathrm{C}$ per decade). For summer, increasing trends were found for each of the investigated series, that is, for mean, median, minimum, and maximum air temperature, with a rate of change of 0.42 $0.53{ }^{\circ} \mathrm{C}$ per decade. Furthermore, monotonic trend analysis was repeated for seasonal water temperature relating to two consecutive time periods before and after the construction of the DR complex (1960-1985, and 1986-2009). At the upstream site, an increase in minimum winter $\mathrm{Tw}\left(0.05{ }^{\circ} \mathrm{C}\right.$ per decade, strong evidence) as well as a decrease in maximum autumn Tw ( $-0.98{ }^{\circ} \mathrm{C}$ per decade) were found for $1960-1985$, while a considerable increase in maximum spring Tw $\left(1.44{ }^{\circ} \mathrm{C}\right.$ per decade, strong evidence) was followed by increases in mean and median $\mathrm{Tw}\left(0.65-0.70{ }^{\circ} \mathrm{C}\right.$ per decade) for the summer of 1986-2009 (Table 4). At the downstream site, no trend in Tw was found for 1960-1985 (Table 5);
Table 4. Rate of change $\hat{a}\left({ }^{\circ} \mathrm{C}\right.$ decade $\left.{ }^{-1}\right)$ for water temperature (Tw) at Stróża. See details in caption of Table 2.

\begin{tabular}{|c|c|c|c|c|}
\hline \multicolumn{5}{|c|}{$1960-1985$} \\
\hline Tw statistic & $\begin{array}{c}\text { Winter } \\
\text { (Dec- } \\
\text { Feb) }\end{array}$ & $\begin{array}{c}\text { Spring } \\
\text { (Mar- } \\
\text { May) }\end{array}$ & $\begin{array}{c}\text { Summer } \\
\text { (Jun- } \\
\text { Aug) }\end{array}$ & $\begin{array}{c}\text { Autumn } \\
\text { (Sep- } \\
\text { Nov) }\end{array}$ \\
\hline Mean & -0.21 & -0.36 & -0.29 & -0.57 \\
\hline Median & -0.08 & -0.67 & -0.30 & -0.25 \\
\hline Minimum & $0.05^{* *}$ & 0.00 & 0.00 & -0.22 \\
\hline Maximum & -0.80 & 0.00 & -0.38 & $-0.98^{*}$ \\
\hline \multirow{5}{*}{ Tw statistic } & $\begin{array}{c}\text { Winter } \\
\text { (Dec- } \\
\text { Feb) }\end{array}$ & $\begin{array}{c}\text { Spring } \\
\text { (Mar- } \\
\text { May) }\end{array}$ & $\begin{array}{c}\text { Summer } \\
\text { (Jun- } \\
\text { Aug) }\end{array}$ & $\begin{array}{c}\text { Autumn } \\
\text { (Sep- } \\
\text { Nov) }\end{array}$ \\
\hline Mean & -0.05 & 0.56 & $0.65^{*}$ & 0.36 \\
\hline Median & -0.10 & 0.58 & $0.70^{*}$ & 0.39 \\
\hline Minimum & 0.00 & 0.00 & 0.62 & 0.00 \\
\hline Maximum & 0.00 & $1.44^{* *}$ & 0.53 & 0.49 \\
\hline
\end{tabular}

* data significant at $p<0.05$; * data significant at $p<0.01$.

Table 5. Rate of change $\hat{a}\left({ }^{\circ} \mathrm{C}\right.$ decade $\left.{ }^{-1}\right)$ for water temperature (Tw) at Proszówki. See details in caption of Table 2.

\begin{tabular}{|c|c|c|c|c|}
\hline \multicolumn{5}{|c|}{$1960-1985$} \\
\hline Tw statistic & $\begin{array}{c}\text { Winter } \\
\text { (Dec- } \\
\text { Feb) }\end{array}$ & $\begin{array}{c}\text { Spring } \\
\text { (Mar- } \\
\text { May) }\end{array}$ & $\begin{array}{c}\text { Summer } \\
\text { (Jun- } \\
\text { Aug) }\end{array}$ & $\begin{array}{c}\text { Autumn } \\
\text { (Sep- } \\
\text { Nov) }\end{array}$ \\
\hline Median & 0.07 & -0.03 & -0.07 & -0.31 \\
\hline Minimum & 0.00 & -0.23 & -0.13 & 0.00 \\
\hline Maximum & 0.00 & 0.81 & -0.25 & 0.17 \\
\hline \multirow{5}{*}{ Tw statistic } & $\begin{array}{c}\text { Winter } \\
(\text { Dec- } \\
\text { Feb) }\end{array}$ & $\begin{array}{c}\text { Spring } \\
\text { Mar- }\end{array}$ & $\begin{array}{c}\text { Summer } \\
\text { (Jun- } \\
\text { Aug) }\end{array}$ & $\begin{array}{c}\text { Autumn } \\
\text { (Sep- } \\
\text { Nov) }\end{array}$ \\
\hline Mean & 0.21 & -0.08 & -0.25 & $0.85^{* *}$ \\
\hline Median & 0.13 & 0.30 & -0.04 & 0.83 \\
\hline Minimum & 0.00 & 0.42 & 0.27 & 0.85 \\
\hline Maximum & -0.23 & -0.91 & $-1.32^{* *}$ & 0.47 \\
\hline
\end{tabular}

* data significant at $p<0.05$; ** data significant at $p<0.01$. 
on the other hand, a decreasing trend in maximum summer Tw $\left(-1.32{ }^{\circ} \mathrm{C}\right.$ per decade, strong evidence) was followed by an increase in mean autumn $\mathrm{Tw}\left(0.85{ }^{\circ} \mathrm{C}\right.$ per decade, strong evidence) for 1986-2009.

\section{Discussion}

On the basis of an exemplary mountain river with a longterm (50-year) record of temperature measurements (for the period 1960-2009), the obtained results suggest that water temperature tends to be progressively higher during the spring (maximum values of Tw shown for the upstream site, Fig. 4a), as well as during the summer (mean, median, and maximum values of Tw shown for the upstream site, Figs. 5a-c). Such increasing tendencies are consistent with the increasing trends found in spring and summer air temperature (Table 3) for 1962-2009 at both studied sites, and for spring and summer Tw for 1986-2009 at the upstream site (Table 4). Increasing trends in spring $\mathrm{Tw}$ are in line with results obtained for a $30-\mathrm{km}^{2}$ catchment in Scotland over the period 1968-1997 [40]. Moreover, increasing summer Tw can also be associated with diminished summer river flow in the Raba catchment for 1985-2014 [41]. If these tendencies continue, the created thermal conditions will likely be unsuitable for native, coldwater fish (e.g. salmonids) inhabiting the Raba River [42]. Conversely, increasing trends in spring and summer Tw are absent for the downstream site (approx. $39 \mathrm{~km}$ from the DR dam with hypolimnetic releases), and even decreasing trends are present for 1960-2009 (maximum values, Fig. $4 \mathrm{~b}$ and 5d, respectively) and 1986-2009 (maximum summer values, Table 5). Other differences in seasonal $\mathrm{Tw}$ at the upstream and downstream sites exist as well, including significant increases in autumn and winter Tw (mean, median, and minimum values, Figs. 2, 3) for 1960-2009, as well as for 1986-2009 (mean autumn Tw, Table 5) at the downstream site only. While increasing trends in winter Tw (mean and median values, Fig. 3), in line with [40], could partly be explained by increasing trends in winter Ta (Table 3), no trends in autumn air temperature were noted for either site (Table 3) for 1962-2009. On the other hand, these discrepancies can be explained by the well-documented impact of dams with hypolimnetic releases, which tend to create warmer conditions in autumn and winter, but cooler conditions in spring and summer [22, 43]. It appears that cooler conditions shaped by the DR dam compensate for an increase in spring and summer Tw downstream.

It is also apparent that the magnitude and/or direction of hydro-climatic trends depend on dynamic interactions between numerous factors acting on river catchments. Specifically, land use and land cover changes (LULCC) are common in the Carpathians due to a major shift in land use after 1990, leading to farm abandonment and forest expansion [44]. According to CLC mapping (data available for the years 1990, 2000, 2006, and 2012), the same direction of LULCC occurred in the Raba catchment over the period 1990-2012. For the Stróża and Proszówki subcatchments, increases in the surface area of developed land (4.0 and $4.2 \%$, respectively) and forest cover (4.4 and 3.3\%, respectively) occurred at the expense of agricultural land; both change factors are of a similar magnitude, but detailed analyses are needed in order to quantify their effects on water and air temperatures as well as river flow.

On the whole, the identified increasing trends in spring and summer water temperature should facilitate adaptive management of the thermal regime of the Raba River upstream from the DR dam in order to mitigate adverse effects of climate warming on this natural fluvial environment. In addition, important differences in the direction of trends in water temperature for the upstream and downstream sites indicate the usefulness of the $39-\mathrm{km}$ downstream river section of the DR dam for coldwater trout fishery production [28].

\section{Conclusions}

In the herein described analysis pertaining to changing thermal conditions in a mountain river, long-term (50year) trends in river water temperature for each season of the year (1960-2009) were found. The direction of these trends differs for sites located some distance upstream and downstream from a relatively large manmade reservoir with hypolimnetic water releases. For the upstream site, Tw tends to be progressively higher in spring (maximum values) and summer (mean, median, and maximum values), in concordance with seasonal air temperature trends. This implies the need for appropriate flowing water management that would mitigate adverse effects of climate warming on the fluvial environment.

For the downstream site, Tw tends to be higher in autumn and winter (mean, median, and minimum values), but lower in spring and summer (maximum values). The identified differences point to an anthropogenic impact on river water temperature downstream from the Dobczyce Reservoir. On the other hand, this creates opportunities for using the 39-km river reach below the DR dam as a natural trout fishery, provided that the DR dam is managed adaptively for changing climate conditions.

This work was supported by the Polish Ministry of Science and Higher Education (grant no. Ś 1/194/2017/DS task 4).

\section{References}

1. J.D. Allan, M.M. Castillo, Stream ecology. Structure and function of running waters (2nd ed., Springer, 2007)

2. J.E. Edinger, D.W. Duttweiler, J.C. Geyer, Water Resour. Res. 4, 1137-1145 (1968)

3. B.A. Sinokrot, H.G. Stefan, Water Resour. Res. 29, 2299-2312 (1993)

4. G.C. Poole, C.H. Berman, Environ. Manage. 27, 787-802 (2001)

5. J.D. Meisner, Trans. Am. Fish. Soc. 119, 282-291 (1990)

6. B.A. Sinokrot, H.G. Stefan, J.H. McCormick, J.G. Eaton, Clim. Change 30, 181-200 (1995) 
7. R.D. Ries, S.A. Perry, Clim. Res. 5, 197-206 (1995)

8. B.W. Webb, Hydrol. Processes 10, 205-226 (1996)

9. O. Mohseni, T.R. Erickson, H.G. Stefan, Water Resour. Res. 35, 3723-3733 (1999)

10. O. Mohseni, H.G. Stefan, J.G. Eaton, Clim. Change 59, 389-409 (2003)

11. M. Daufresne, M.C. Roger, H. Capra, N. Lamouroux, Glob. Change Biol. 10, 123-140 (2004)

12. R.E. Hari, D.M. Livingstone, R. Siber, P. BurkhardtHolm, H. Güttinger, Glob. Change Biol. 12, 10-26 (2006)

13. A.C. Johnson, M.C. Acreman, M.J. Dunbar, S.W. Feist, A.M. Giacomello, R.E. Gozlan, S.A. Hinsley, A.T. Ibbotson, H.P. Jarvie, J.I. Jones, M. Longshaw, S.C. Maberly, T.J. Marsh, C. Neal, J.R. Newman, M.A. Nunn, R.W. Pickup, N.S. Reynard, C.A. Sullivan, J.P. Sumpter, R.J. Williams, Sci. Total Environ. 407, 4787-4798 (2009)

14. D.L. Hartmann, A.M.G. Klein Tank, M. Rusticucci, L.V. Alexander, S. Brönnimann, Y. Charabi, F.J. Dentener, E.J. Dlugokencky, D.R. Easterling, A. Kaplan, B.J. Soden, P.W. Thorne, M. Wild, P.M. Zhai, Observations: Atmosphere and Surface, in: Climate Change 2013: The Physical Science Basis. Contribution of Working Group I to the Fifth Assessment Report of the Intergovernmental Panel on Climate Change (Cambridge University Press, 2013)

15. K.E. Trenberth, Clim. Res. 47, 123-138 (2011)

16. J.J. Magnuson, L.B. Crowder, P.A. Medvick, Am. Zool. 19, 331-343 (1979)

17. C.C. Coutant, Environ. Biol. Fishes 18, 161-172 (1987)

18. G.W. Brown, J.T. Krygier, Water Resour. Res. 6, 1133-1139 (1970)

19. N.H. Ringler, J.D. Hall, Trans. Am. Fish. Soc. 104, 111-121 (1975)

20. B.W. Webb, D.E. Walling, Appl. Geogr. 16, 211227 (1996)

21. C.L. Lowney, Water Resour. Res. 36, 29473-2955 (2000)

22. N.L. Poff, D.D. Hart, Bioscience 52, 659-668 (2002)

23. J.L. Lessard, D.B. Hayes, River Res. Appl. 19, 721732 (2003)

24. D. Caissie, Freshw. Biol. 51, 1389-1406 (2006)

25. M. Kędra, Reservoir-induced changes in dynamics and synchrony of river water temperatures revealed by RQA and CRQA, in: Recurrence plots and their quantifications: expanding horizons (Springer Proceedings in Physics, 180, Springer, pp. 289-300, 2016)

26. M. Kędra, Ł. Wiejaczka, Water Environ. J. 30, 3139 (2016)

27. J.D. Olden, R.J. Naiman, Freshw. Biol. 55, 86-107 (2010)
28. C.W. Krause, T.J. Newcomb, J.D. Orth, River Res. Applic. 21, 581-593 (2005)

29. W. Chełmicki, Location, classification and characteristics of the basin, in: The Upper Vistula Basin, part I (In Polish, PWN Warszawa-Kraków, pp. 15-29, 1991)

30. S. Kurek, A. Misztal, J. Pawlik-Dobrowolski, Natural environment as a factor controlling runoff and chemical composition of water in the Raba catchment, in: The Raba catchment as an area of recharge of water and pollutants for the reservoir in Dobczyce (In Polish, Politechnika Krakowska, Monogr. 145, pp. 13-31, 1993)

31. CLC 2012, http://land.copernicus.eu/pan-european/ corine-land-cover (accessed 4 May 2017)

32. J. Hennig, I. Hennig, A. Roszkowski, Retention reservoirs, in: The Upper Vistula Basin, part II (In Polish, PWN, Warszawa-Kraków, pp. 121-143, 1991)

33. S. Szalai, I. Auer, J. Hiebl, J. Milkovich, T. Radim, P. Stepanek, P. Zahradnicek, Z. Bihari, M. Lakatos, T. Szentimrey, D. Limanówka, P. Kilar, S. Cheval, Gy. Deak, D. Mihic, I. Antolovic, P. Nejedlik, P. Stastny, K. Mikulova, I. Nabyvanets, O. Skyryk, S. Krakovskaya, Climate of the Greater Carpathian Region (Final Technical Report, 2013, www.carpatclim-eu.org)

34. H.B. Mann, Econometrica 13, 245-259 (1945)

35. M.G. Kendall, Rank correlation methods (4th edn., Charles Griffin, London, 1975)

36. D.R. Helsel, R.M. Hirsch, Statistical methods in water resources. Techniques of water-resources investigations (Book 4, U.S. Geological Survey, 2002) https://pubs.usgs.gov/twri/twri4a3/ (accessed 17 July 2017)

37. H. Theil, Proc. R. Neth. Acad. Arts Sci. 53, 386392, 521-525, 1397-1412 (1950)

38. P.K. Sen, J. Am. Stat. Assoc. 63, 1379-1389 (1968)

39. S. Yue, P. Pilon, B. Phinney, G. Cavadias, Hydrol. Process. 16, 1807-1829 (2002)

40. S.J. Langan, L. Johnston, M.J. Donaghy, A.F. Youngson, D.W. Hay, C. Soulsby, Sci. Total Environ. 265, 195-207 (2001)

41. M. Kędra, Clim. Res. 72, 251-265 (2017)

42. K. Bieniarz, P. Epler, Ichthyofauna, in: The Upper Vistula Basin, part II (In Polish, PWN WarszawaKraków, pp. 69-81, 1991)

43. R. Soja, Ł. Wiejaczka, Water Environ. J. 28, 473482 (2014)

44. A. Björnsen Gurung, A. Bokwa, W. Chełmicki, M. Elbakidze M. Hirschmugl, P. Hostert, P. Ibisch, J. Kozak, T. Kuemmerle, E. Matei, K. Ostapowicz, J. Pociask-Karteczka, L. Schmidt, S. van der Linden, M. Zebisch, Mt. Res. Dev. 29, 282-288 (2009) 